\title{
Interpretation of the Early Cretaceous mammal Peraiocynodon (Docodonta) and taxonomy of some British Mesozoic docodonts
}

\begin{abstract}
Alexander O. Averianov
ABSTRACT. Interpretation of the dentition in the holotype of Peraiocynodon inexpectatus Simpson, 1928 as d1-4 (Butler, 1939) is confirmed. Two taxa of docodonts from the British Middle Jurassic are based on the lower milk teeth: Cyrtlatherium canei and Peraiocynodon major. Simpsonodon oxfordensis Kermack et al., 1987 is a junior subjective synonym of Cyrtlatherium canei Freeman, 1979 (syn. nov.) and Peraiocynodon major Sigogneau-Russell, 2003 is a junior subjective synonym of Krusatodon kirtlingtonensis Sigogneau-Russell, 2003 (syn. nov.).
\end{abstract}

KEY WORDS: Peraiocynodon, Docodonta, deciduous dentition.

Alexander O. Averianov [sasha@AA1923.spb.edu], Zoological Institute of the Russian Academy of Sciences, Universitetskaya nab. 1, Saint Petersburg 199034, Russia.

\section{Интерпретация раннемелового млекопитающего Peraiocynodon (Docodonta) и таксономия некоторых докодонтов из мезозоя Великобритании}

\begin{abstract}
А.О. Аверьянов
РЕЗЮМЕ. Подтверждена интерпретация зубов на голотипе Peraiocynodon inexpectatus Simpson, 1928 как d1-4 (Butler, 1939). Два таксона докодонтов из средней юры Великобритании основаны на молочных зубах: Cyrtlatherium canei и Peraiocynodon major. Simpsonodon oxfordensis Kermack et al., 1987 является младшим субъективным синонимом Cyrtlatherium canei Freeman, 1979 (syn. nov.) и Peraiocynodon major Sigogneau-Russell, 2003 - младший субъективный синонимKrusatodon kirtlingtonensis Sigogneau-Russell, 2003 (syn. nov.).
\end{abstract}

КЛЮЧЕВЫЕ СЛОВА: Peraiocynodon, Docodonta, молочные зубы.

Docodonta were a small but successful group of Mesozoic mammals with a complex shearing and crushing dentition functionally paralleling that of tribosphenic mammals. Our knowledge of the group has been greatly improved during the past few years (see Sigogneau-Russell, 2003; Martin \& Averianov, 2004; and Kielan-Jaworowska et al., in press for recent reviews). For a long time the group was represented only by a single taxon, the Late Jurassic North American Docodon Marsh, 1881. The second docodont taxon to be described was the monotypic Peraiocynodon inexpectatus Simpson, 1928, based on a single lower jaw from the Early Cretaceous (Berriasian) Purbeck Limestone Group of England (Simpson, 1928). The dentary is anteriorly incomplete and lacks most of the coronoid process, with four molariform teeth which are gradually increasing in size posteriorly, and an unerupted tooth behind them. The four erupted and one unerupted teeth were originally interpreted as $\mathrm{m} 1-5$ with the remark that "further molars may [...] have appeared later in life" (Simpson, 1928: 127).

This interpretation was challenged by Butler (1939) who considered the four molariform teeth to be deciduous premolars, dp1-4, and concluded that Peraiocyn- odon may prove to be synonymous with Docodon. Butler's interpretation was accepted by a number of authors (e.g., Patterson, 1956; Simpson, 1961; Kron, 1979; Kielan-Jaworowska et al., in press), but not by Krusat (1980) who, based on the observed similarity between the corresponding teeth in Peraiocynodon and the Late Jurassic Haldanodon Kühne \& Krusat, 1972, considered the teeth of the former as $\mathrm{p} 1, \mathrm{dp} 2-3, \mathrm{~m} 1$, and $\mathrm{m} 2$ (tooth bud).

Krusat's interpretation was partially supported by Sigogneau-Russell (2001: 429), who designated the penultimate and ultimate teeth in Peraiocynodon as "?d3 and ?first lower molar", and by Sigogneau-Russell and Kielan-Jaworowska (2002: 243), who further commented that "if it is practically certain that the last molar preserved on the type specimen [of Peraiocynodon] is indeed definitive [...] doubt persists as to the deciduous nature of the two more anterior teeth, since two similar teeth have been found in the new small hypodigm". The meaning of the latter statement is elusive for me, I cannot see how the discovery of similar isolated teeth may affect the interpretation of the dental formula in the Peraiocynodon holotype. Later Sigogneau-Russell (2003) repeated this interpretation, described isolated 


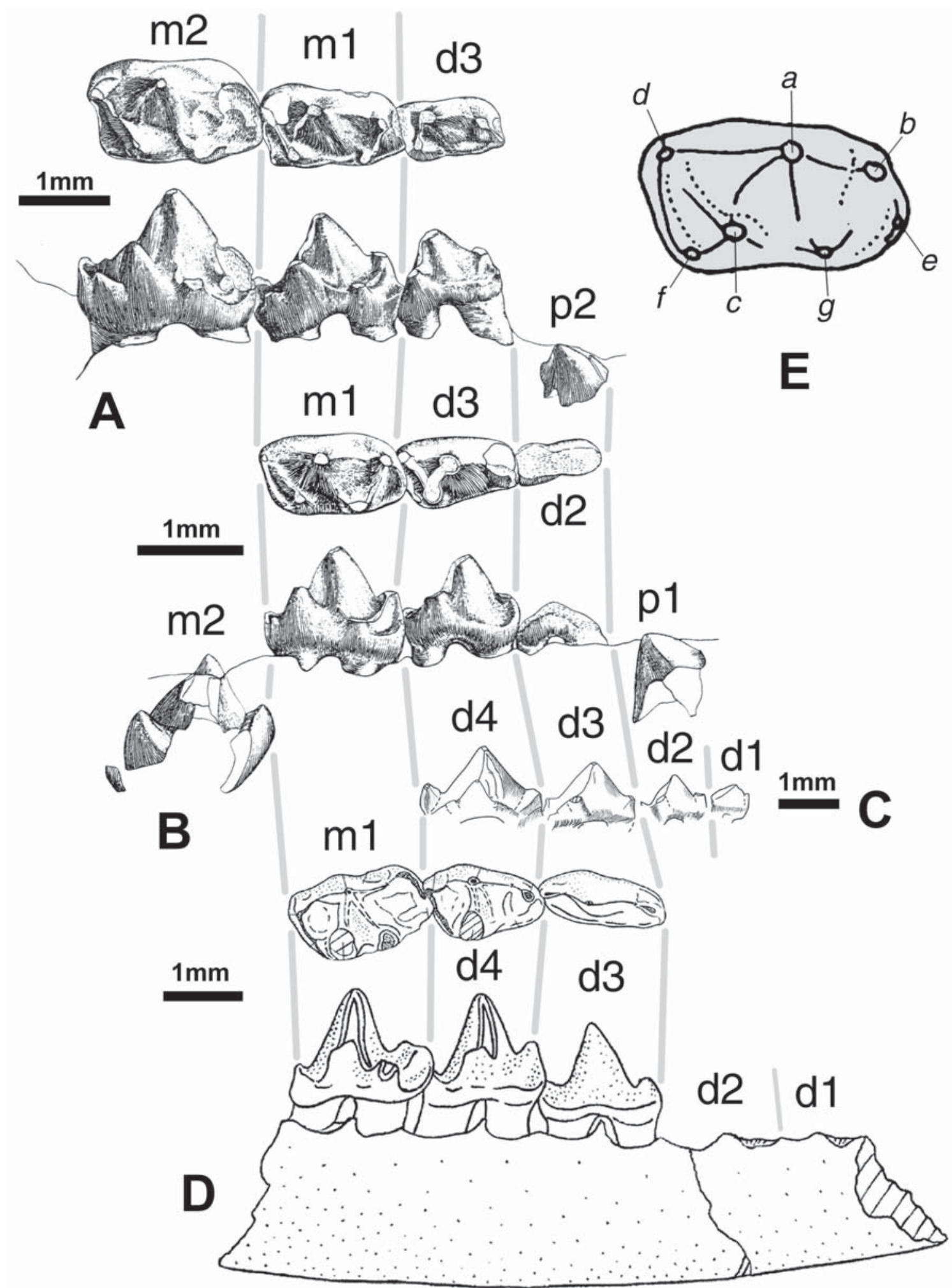

Figure 1. Lower deciduous teeth and anterior molars of Docodonta (A-D) and cusp nomenclature for a docodont left lower molar (E, anterior is to the right).

A, B - right d $3 \mathrm{~m} 1-2$ (A) and d2-3 $\mathrm{m} 1$ (B) (reversed) of Haldanodon exspectatus from the Upper Jurassic of Portugal, in occlusal and lingual view (after Krusat, 1980); C - left d1-4 of Peraiocynodon inexpectatus from the Lower Cretaceous of England in lingual view (after Sigogneau-Russell, 2003); D - left d3-4 m1 of Sibirotherium rossicus from the Lower Cretaceous of West Siberia, Russia, in occlusal and lingual view (after Maschenko et al., 2003). 
teeth attributed to Peraiocynodon from the Purbeck Limestone, and established a new species of this genus, $P$. major from the Middle Jurassic Kirtlington locality in England. The sample from the Purbeck Limestone included eight lower teeth, three of which conform to the ultimate tooth in the Peraiocynodon holotype, three more posterior teeth, and two notably larger teeth. She explained this variation in favor of presence of two taxa in the sample: Docodon sp. (two larger lower molars) and Peraiocynodon (six remaining teeth). An alternative interpretation, postulating presence of deciduous and permanent teeth of a single taxon, was rejected because "it seems unlikely that we would have here six deciduous teeth for two permanent molars of one single taxon" (Sigogneau-Russell, 2003: 370). This reason by no means can be accepted because: 1) the sample is too small, 2) in some environments and localities deciduous teeth may be quite abundant, possibly because of a high juvenile mortality (see Cifelli, 1999 for an example).

After considering all arguments concerning the interpretation of the Peraiocynodon dental formula, I found that Butler's interpretation is the best established and that all attempts to challenge it are not convincing. The close similarity of the fourth tooth in Peraiocynodon with $\mathrm{m} 1$ in Haldanodon, postulated by Krusat, ignores the fact that this tooth lacks the cusp $g^{1}$ [mesiolingual cusp of descriptive nomenclature], which is present in $\mathrm{m} 1$ and other molars ofHaldanodon and other docodonts. Moreover, all known milk premolars of docodonts lack the cusp $g$ (Fig. 1), which makes it easy to identify them. According to Sigogneau-Russell (2003: tab.4) the mesio-lingual cusp of the lower molars (cusp $g$ ) is absent (designated as " 0 ") in Cyrtlatherium, Peraiocynodon inexpectatus and $P$. major, almost absent in Haldanodon $(+/ 0)$ and Docodon $(0 /+)$, weakly to normally developed in Borealestes serendipitus $(+)$ and $B$. mussettae ${ }^{2}(+)$, and strongly developed in Simpsonodon, Krusatodon, and Tegotherium (+++).

In my opinion the condition of the cuspg in Haldanodon and Docodon cannot be compared with that in Peraiocynodon and Cyrtlatherium, where this cusp is totally lacking. InHaldanodon and Docodon (Figs. 1, 2) cusp $g$ is very low, but in the occlusal view it is quite distinct, being similar in size to the $\operatorname{cusp} c$. So, the taxa really lacking cusp $g$ (Cyrtlatherium and two species of Peraiocynodon) are based on milk teeth. Peraiocynodon possibly is synonymous with Docodon, but currently this cannot be proven because the permanent dentition of the Purbeck docodont is insufficiently known. Sigogneau-Russell (2001, 2003) acknowledged that Cyrtlatherium might represent a milk tooth of Simpsonodon from the same Kirtlington locality but eventually discarded this possibility because of its smaller size (length $=0.83 \mathrm{~mm}$ against 1.09 for the smallest molar of Simpsonodon), and because it is relatively narrower

1 I follow docodont cusp nomenclature proposed by Butler (1997), the rationale for this is explained in Martin \& Averianov (2004).

2 The species name is corrected after the original "mussetti" because the species was named after a woman (ICZN Article 31.1.2).

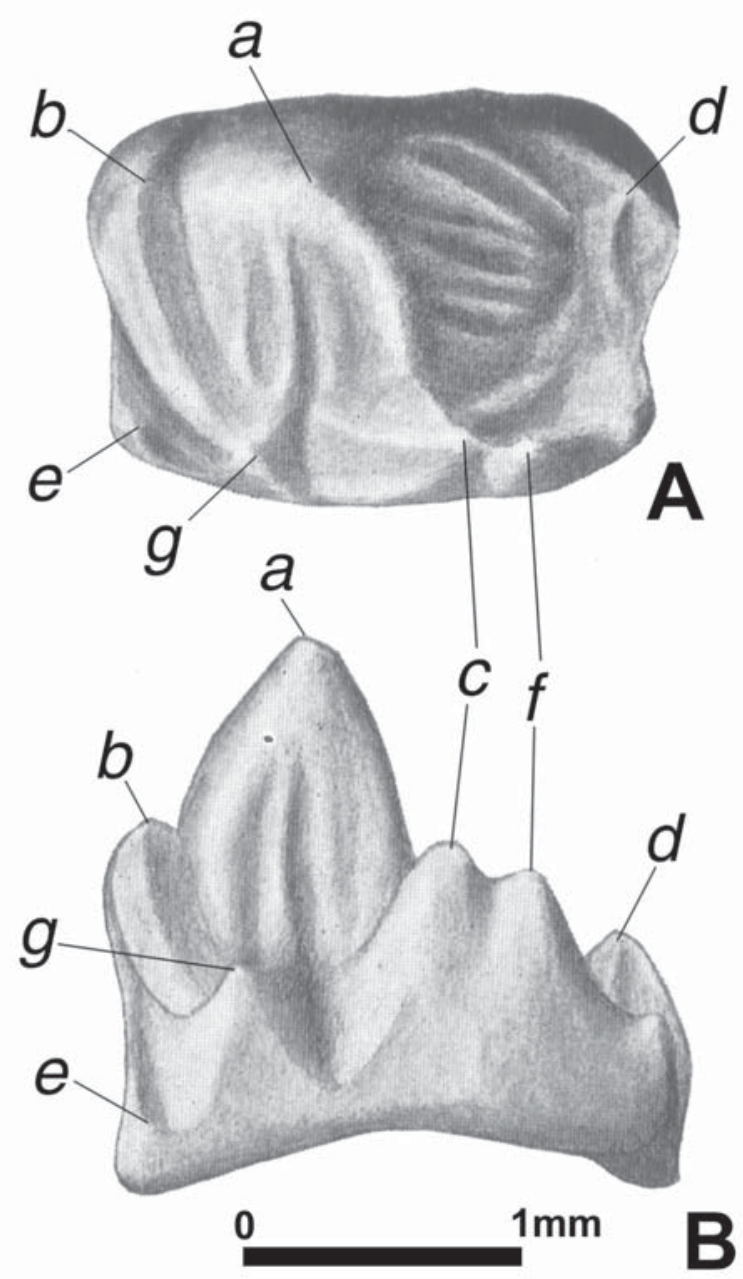

Figure 2. A right lower molar of Docodon sp. from the Upper Jurassic Morrison Formation (Wyoming, USA) in occlusal (A) and lingual (B) views (anterior is to the right) with cusp nomenclature (modified after Vandebroek, 1961).

buccolingually; this and some other characters listed in my opinion just differentiate deciduous from permanent teeth and are not useful for taxon determination. The stated difference in size is also misleading because a deciduous tooth should be compared with premolars, not molars. The last premolar in the holotype of Simpsonodon oxfordensis is $0.93 \mathrm{~mm}$ long (Kermack et al., 1987: 7), and thus the holotype of Cyrtlatherium canei, which is $0.83 \mathrm{~mm}$ in length, perfectly fits this dental locus and most probably represents the ultimate deciduous premolar, dp3 or dp4, depending on how much premolar loci this taxon had (the number of lower premolars varies in docodonts from three in Haldanodon to four in Docodon and Sibirotherium).

I believe that there are now enough data to consider Simpsonodon oxfordensis Kermack et al., 1987 a junior subjective synonym of Cyrtlatherium canei Freeman, 1979 (syn. nov.). Two relatively large deciduous teeth, which constitute the hypodigm ofPeraiocynodon major 
(length $=2.15,2.70)$, may belong to the similarly large taxon Krusatodon kirtlingtonensis from the same Kirtlington mammal bed. If so, Peraiocynodon major Sigogneau-Russell, 2003 may be a junior subjective synonym of Krusatodon kirtlingtonensis Sigogneau-Russell, 2003 (syn. nov.). Concluding, the docodont fauna of the Kirtlington consist of four species: Cyrtlatherium canei [=Simpsonodon oxfordensis], Borealestes serendipitus, B. mussettae, and Krusatodon kirtlingtonensis [=Peraiocynodon major].

Finally, the phylogenetic position of Krusatodon, which has a well-developed pseudotalonid, requires some remarks. Sigogneau-Russell (2003) compared Krusatodon with Tegotherium from the Late Jurassic of Mongolia (Tatarinov, 1994; Kielan-Jaworowska et al., 2000), and noted that these two taxa may be synonymous. This similarity is due to convergence in my opinion, however.Krusatodon, as well as Cyrtlatherium (=Simpsonodon), clearly belong to the Euroamerican clade of docodonts (see Martin \& Averianov, 2004 for details), where the pseudotalonid is bordered anteriorly by crest $b-g$ [antero-main crest]. In Asian docodonts it is bordered by the $b-e$ and $e-g$ crests, and the crest $b-g$ is reduced.

ACKNOWLEDGEMENTS. I am grateful to Prof. Zofia Kielan-Jaworowska and Drs. Thomas Martin and Alexei Lopatin for reading of this text and comments. This work was supported by the President's of Russia grant MD-255.2003.04, by the Russian Fund of Basic Research grants 04-04-49113 and 04-04-49637, and by the Russian Science Support Foundation.

\section{References}

Butler P.M. 1939. The teeth of the Jurassic mammals // Proceedings of the Zoological Society of London, Series B. Vol.109. P.329-356.

Butler P.M. 1997. An alternative hypothesis on the origin of docodont molar teeth // Journal of Vertebrate Paleontology. Vol.17. No.2. P.435-439.

Cifelli R.L. 1999. Therian teeth of unusual design from the medial Cretaceous (Albian-Cenomanian) Cedar Mountain Formation, Utah // Journal of Mammalian Evolution. Vol.6. No.3. P.247-270.

Kermack K.A., Lee A.J., Lees P.M. \& Mussett F. 1987. A new docodont from the Forest Marble // Zoological Journal of the Linnean Society. Vol.89. P.1-39.

Kielan-Jaworowska Z., Novacek M.J., Trofimov B.A. \& Dashzeveg D. 2000. Mammals from the Mesozoic of Mongolia // Benton M.J., Shishkin M.A., Unwin D.M. \& Kurochkin E.N. (eds.). The Age of Dinosaurs in Russia and Mongolia. Cambridge: Cambridge University Press.
P.573-626.

Kielan-Jaworowska Z., Cifelli R.L. \& Luo Z.-X. in press. Mammals from the Age of Dinosaurs: Origins, Relationships, and Structure. New York: Columbia University Press.

Kron D.G. 1979. Docodonta // Lillegraven J.A., KielanJaworowska Z. \& Clemens W.A. (eds.). Mesozoic Mammals: the First Two-Thirds of Mammalian History: Berkeley, Los Angeles \& London: University of California Press. P.91-98.

Krusat G. 1980. Contribução para o conhecimento da fauna do Kimeridgiano da mina de lignito Guimarota (Leiria, Portugal). IV Parte. Haldanodon exspectatus Kühne \& Krusat 1972 (Mammalia, Docodonta) // Memórias dos Serviços Geológicos de Portugal. Vol.27. P.1-79.

Martin T. \& Averianov A.O. 2004. A new docodont (Mammalia) from the Middle Jurassic of Kyrgyzstan, Central Asia // Journal of Vertebrate Paleontology. Vol.24. No.1. P.195-201.

Maschenko E.N., Lopatin A.V. \& Voronkevich A.V. 2003. A new genus of the tegotheriid docodonts (Docodonta, Tegotheriidae) from the Early Cretaceous of West Siberia // Russian Journal of Theriology. Vol.1. No.2. P.75-81.

Patterson B. 1956. Early Cretaceous mammals and the evolution of mammalian molar teeth // Fieldiana: Geology. Vol.13. No.1. P.1-105.

Sigogneau-Russell D. 2001. Docodont nature of Cyrtlatherium, an upper Bathonian mammal from England // Acta Palaeontologica Polonica. Vol.46. No.3. P. 427-430.

Sigogneau-Russell D. \& Kielan-Jaworowska Z. 2002. Mammals from the Purbeck Limestone Group of Dorset, southern England // Special Papers in Palaeontology. Vol.68. P.21-255.

Sigogneau-Russell D. 2003. Docodonts from the British Mesozoic// Acta Palaeontologica Polonica. Vol.48. No.3. 357-374.

Simpson G.G. 1928. A Catalogue of the Mesozoic Mammalia in the Geological Department of the British Museum. London: British Museum (Natural History). 215 p.

Simpson G.G. 1961. Evolution of Mesozoic mammals // Vandebroek G. (ed.). International Colloquium on the Evolution of Lower and Non-specialized Mammals. Brussels: Koninklijke Vlaamse Academie voor Wetenschappen, Letteren en Schone Kunsten van Belgie. Vol.1. P.57-95.

Tatarinov L.P. 1994. [On an unusual mammalian tooth from the Mongolian Jurassic] // Paleontologicheskii Zhurnal. No.2. P.97-105 [in Russian].

Vandebroek G. 1961. The comparative anatomy of the teeth of lower and non specialized mammals // Vandebroek G. (ed.). International Colloquium on the Evolution of Lower and Non-specialized Mammals: Brussels: Koninklijke Vlaamse Academie voor Wetenschappen, Letteren en Schone Kunsten van Belgie. Vol.1. P.215-320; Vol.2. 181 p. (44 plates). 